\title{
Thermal and mechanical evolution of collisional and accretionary orogens: a volume in honour of Karel Schulmann-an introduction
}

\author{
P. Štípská ${ }^{1,2} \cdot$ P. Hasalová ${ }^{1} \cdot$ P. Jeřábek ${ }^{3} \cdot$ O. Lexa ${ }^{3} \cdot$ J. M. Lardeaux ${ }^{4} \cdot M$. Sun $^{5} \cdot$ J. W. Cosgrove ${ }^{6}$
}

Published online: 30 May 2020

○) Geologische Vereinigung e.V. (GV) 2020

Professor Karel Schulmann (Fig. 1) is a scientific leader in the domain of structural geology, tectonics of collisional and accretionary systems and geodynamic processes in general. His publication record is impressive both in terms of quality and quantity (190 refereed papers and over 6200 citations). Karel Schulmann has basically founded the modern basement geology community in the Czech Republic and greatly contributed to the development of this discipline in France. This volume is an outcome of a conference in honour of Karel Schulmann's 60th birthday entitled Thermal and mechanical evolution of collisional and accretionary orogens held in Třešl, Czech Republic from August 31st to September 2nd, 2018. This conference featured over 50 contributions from colleagues, former students and friends all around the world and 17 selected contributions are presented in this volume.

Karel began his career in 1983 in the former Czechoslovakia working as a structural geologist in the Central Geological Institute, now the Czech Geological Survey. After the Velvet Revolution in 1989, and particularly in 1991, when he moved to the Faculty of Science at the Charles

P. Štípská

stipska@gmail.com

1 Centre for Lithospheric Research, Czech Geological Survey, Klarov 3, Prague 1, Czech Republic

2 Institute de Physique de Globe, UMR 7516, Université de Strasbourg, 1 Rue Blessig, 67084 Strasbourg, France

3 Institute of Petrology and Structural Geology, Charles University, 12843 Prague 2, Czech Republic

4 Géoazur, Université Nice Sophia-Antipolis, 250 Rue A. Einstein, Sophia-Antipolis, 06560 Valbonne, France

5 Department of Earth Sciences, The University of Hong Kong, Pokfulam Road, Hong Kong, China

6 Qatar Carbonate and Carbon Capture Research Centre and Department of Earth Science and Engineering, Imperial College London, Prince Consort Road, London SW7 2BP, UK
University, he greatly restored contacts with the European scientific community and through numerous international collaborations developed modern geodynamic research, which included petrology, geochronology, geophysics and mathematics. At Charles University, he established a modern Department of Structural Geology and Petrology and was in charge of it until 2004. During this time, he submitted his Habilitation Thesis in 1992 and he was appointed associate professor, and then full professor in 2001. The Department soon gathered a high regard and became renowned among students, teaching staff and scientific community as a whole. It was Karel's enthusiasm in science and teaching, together with his warm and friendly attitude to his former students, and people in general, which opened the door to international science and placed firmly his Institute of Petrology and Structural Geology in Prague on the European map of structural geology, metamorphic petrology and tectonics. Later Karel moved to France where he was appointed to a professorship at Strasbourg University in 2004. In 2012, he received a significant grant from the Czech government and established within the Czech Geological Survey a Centre for Lithospheric Research. In 2015, he was appointed "Professor of exceptional class of French Universities" and in 2018, he became an Honorary Professor of the department of Earth Sciences at the University of Hong Kong.

His unique phenomenological approach to structural geology deploying the latest quantitative laboratory techniques has always been focused on mechanical and physical processes that gave rise to deformation structures. This approach demands a great deal of diversity and a capacity for bridging scales and disciplines for which Karel is well equipped. His skills in the use of the multi-disciplinary approach to research in tectonic studies have inspired many structural geologists and metamorphic petrologists and provide an example of good practice in tectonic studies. Karel is especially recognized for his exemplary and innovative work on the understanding of continental collision related to the Paleozoic orogeny in Europe 


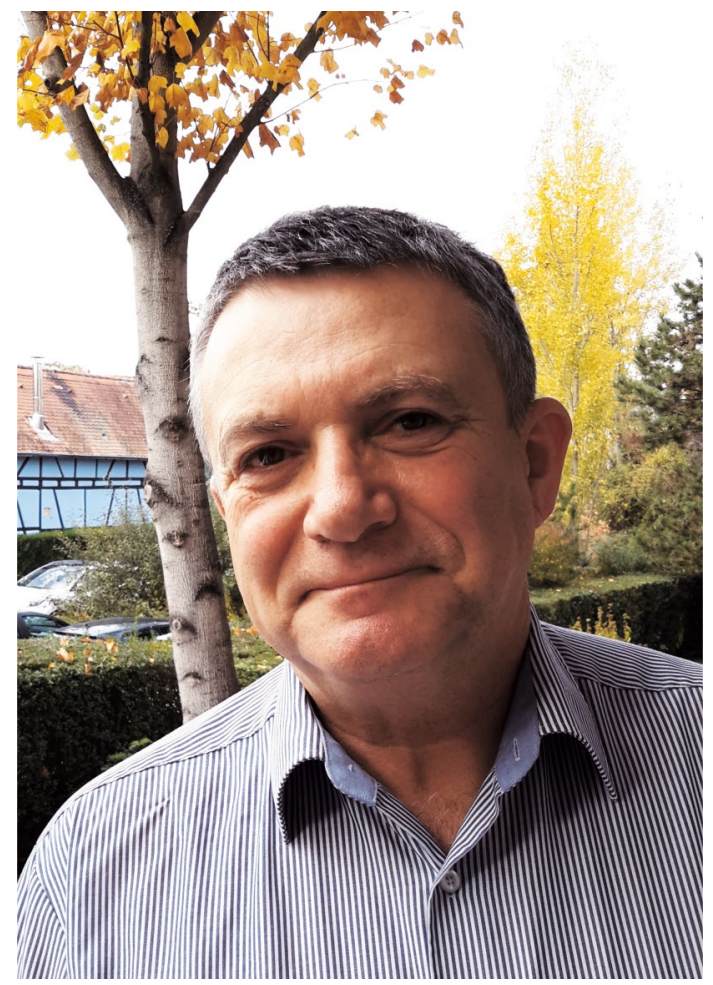

Fig. 1 Karel Schulmann in Strasbourg, France (October, 2018)

involving relamination of lower plate crust and its gravity driven exhumation. In constructing geodynamic models, Karel collates pieces of evidence, from a wide variety of sources using a number of advanced techniques. These include rock assemblages, microstructure, thermodynamic modelling, high-resolution geochronology, rock rheology, and geophysical and numerical modelling. Consequently, his models are extremely robust and able to provide fundamental contributions to key aspects of the processes involved in the evolution of orogens. As an enthusiast and creative intellectual, Karel has also led and encouraged novel and original research in the fields of rock rheology, the formation of fabrics, metamorphic petrology, transformation of rocks by melt percolation, pluton emplacement and particle behaviour in magma flow. His current work in the Central Asian Orogenic Belt (Fig. 2) focuses on questions related to the structure and evolution of this vast accretionary orogen and on the general mechanism of unprecedented Phanerozoic continental growth. The rare equilibrium between his deep knowledge of Earth Sciences, his extraordinary observational skills, his phenomenal factographic memory and his creative and innovative ideas made Karel an extraordinary synergic scientist that over the years became a respected and valued member of the international geological community. Karel is not only a brilliant geoscientist but also a human being in the best sense of this word with his excellence and imperfections.
This special issue is a testament to his career achievements and his enduring friendships with his colleagues and students.

This special issue of International Journal of Earth Sciences comprises papers submitted by colleagues and friends of Karel Schulmann to celebrate his lifelong contribution to structural geology, tectonics and geodynamics of the European and Asian Paleozoic belts, Mesozoic West Carpathian orogeny and Proterozoic orogeny in Africa. The manuscripts are linked together by the common thread of understanding evolution of collisional and accretionary orogens. The authors do this using a variety of methods from detailed field and microstructural observations, petrological work, thermodynamic modelling, modern geochronology and anisotropy of magnetic susceptibility method. The topics in this volume cover a broad range of subjects related to orogenic processes from the European Variscan belt, especially from the Iberian and Bohemian Massifs and from the Variscan basement within the Alps, from Alpine tectonics in the West Carpathians and Alps as well as new views on orogeny in Angola, Madagascar and China.

Martínez Catalán et al. present a correlation of the NW Iberian Allochthon, and the Teplá-Barrandian and Moldanubian Zones representing the internal parts of the Variscan belt in the NW Iberian Massif and Bohemian Massif. The correlation explores the lithological association, protolith ages, metamorphic evolution, detrital zircon age spectra and tectonic setting in the respective units to investigate whether the two remote domains could have formed part of the same allochthonous stack. Early Variscan, subductionrelated high-pressure metamorphism characterizes many of the correlated allochthonous units, with ages younging from the structurally upper to the lower units from 400-385 to 370-360 Ma, respectively. High- and ultrahigh-pressure metamorphism occurred also at 360-340 Ma in the Saxothuringian Autochthon, but not in the NW Iberian Autochthon. The different behaviour of the Autochthon in the Iberian and Bohemian massifs accounts for their distinct evolutions from 360 Ma onwards.

Mazur et al. present a new tectonic model for the eastern termination of the Central European Variscan belt. It is based upon high-resolution geological and geophysical data especially for the subsurface in Poland, up to its SE border, derived from drillings, seismic lines and potential field mapping. They present new findings that concern the far-reaching extent of external fold-and-thrust belt and integrate them into an overall kinematic model for the north-easternmost Variscides. The authors approach and revisit the concept of oroclinal bending, which is one of the most emblematic tectonic structures of the European Variscan belt.

Štípská et al. detail the Barrovian inverted metamorphism of the Svratka dome in the Bohemian Massif, Czech Republic and compare it with the nearby Thaya dome. Whilst the 


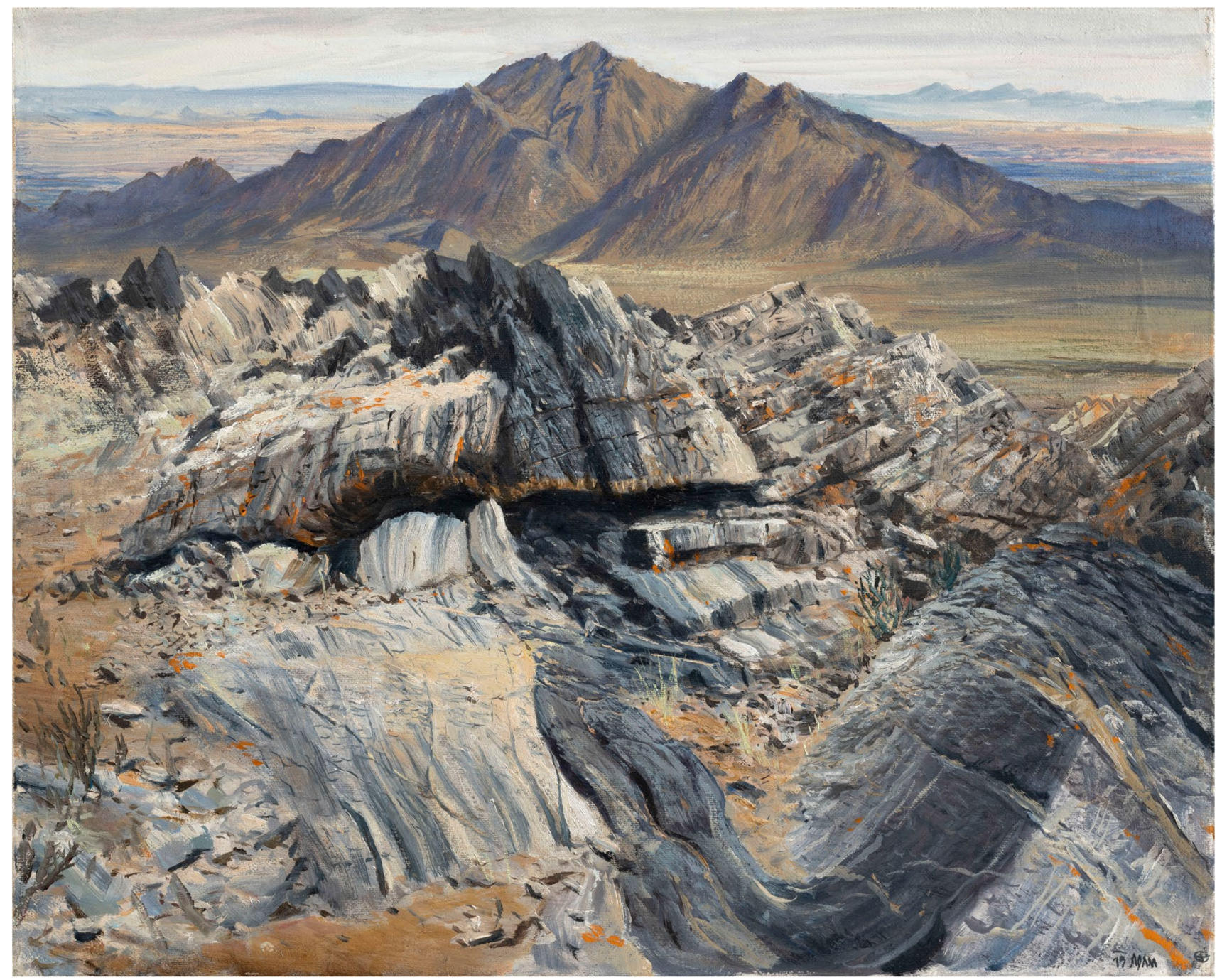

Fig. 2 Marbles in Mongol Altai. Painting by Adam Kašpar done during field expedition led by Karel Schulmann in 2019. Oil on canvas, $40 \times 50 \mathrm{~cm}$

petrological and geochronological data are consistent, the spacing and distribution of metamorphic zones, nappe thicknesses, and late structures are different in the two domes. To explain these, they propose a new tectonic model in which the regular spacing of metamorphic isograds in the Thaya dome is explained by a hot overriding Moldanubian domain with high proportion of exhumed hot lower crust. In contrast, the extreme attenuation of metamorphic isograds at the top of the nappe pile of the Svratka dome is explained by thrusting of a relatively cold Moldanubian domain, formed mainly of middle crust.

Peřestý et al. present a detailed structural study of the polyphase early-Variscan structural record associated with a complex and highly heterogeneous detachment system located along the superstructure-infrastructure transition zone. The restoration of deformation history using a 3D kinematic model is applied to interpret complex structural patterns as the result of progressive transposition of two deformation fabrics. The early fabrics are associated with crustal thickening and overprinted by the foliation developed during exhumation of deeper parts of the infrastructure. The authors demonstrated that such a restoration technique coupled with well-constrained pressure-temperature estimates can be successfully applied to reconstruct tectonic history of orogenic interiors affected by complex polyphase deformation.

Aguilar et al. present a detailed characterization of a gradual transition from banded to schlieren and nebulitic orthogneiss in the high-pressure granitic orthogneiss of the south-eastern Orlica-Śnieżnik Dome (NE Bohemian Massif). The transition is characterized by increasing the presence of interstitial phases along like-like grain boundaries and by progressive replacement of recrystallized K-feldspar grains by fine-grained myrmekite. These textural changes 
are characteristic for syn-deformational grain-scale melt percolation, which is in line with the observed enrichment of the rocks in incompatible elements such as REEs, $\mathrm{Ba}, \mathrm{Sr}$, and $\mathrm{K}$, suggesting open-system behaviour with melt passing through the rocks. The $\mathrm{P}-\mathrm{T}$ path deduced from the thermodynamic modelling indicates decompression from $\sim 15-16$ kbar and $\sim 650-740{ }^{\circ} \mathrm{C}$ to $\sim 6 \mathrm{kbar}$ and $\sim 640{ }^{\circ} \mathrm{C}$ with melt present at the $\mathrm{P}-\mathrm{T}$ peak conditions. The $6-8 \mathrm{~km}$ wide zone of vertical foliation and migmatite textural gradients is interpreted as a vertical crustal-scale channel where the grainscale melt percolation was associated with horizontal shortening and vertical flow of partially molten crustal wedge en masse.

Ilnicki et al. present arguments for petrogenesis and tectonic significance of the tholeiitic- and boninite-series metabasites of the Nové Město Unit, around the core of the Orlica-Śnieżnik Dome, Bohemian Massif. They reported for the first time boninites from the envelope of the OSD, which, together with the tholeiites and low-Ti tholeiites provide good constraints on the nature of their mantle sources and partial melting conditions. With trace elements and Nd isotope data, they demonstrated that random fluxing regime of the mantle sources by sediment- and slab-derived melts and fluids played a critical role in the genesis of the tholeiiticand boninitic magmas. Based on geochemical modelling, they propose a two-stage tectonic model where development of the back-arc domain terminated by the ridge subduction, followed by a slab window opening and generation of the boninitic magma at the end of the subduction zone activity. This study also shows that the Nové Město and Zábřeh units are the eastern extension of the Teplá-Barrandian unit and a part of the Cadomian active margin located between the Davle arc complex and the Gondwana mainland.

Jouffray et al. present structural, geochemical, petrological and ${ }^{40} \mathrm{Ar} /{ }^{39} \mathrm{Ar}$ geochronological data performed on Variscan eclogites from the Argentera-Mercantour Massif, southwestern Alps. Based on high-resolution field mapping, they present new eclogite occurrences and discuss the relationships between eclogites and surrounding migmatites. They recognized for the first time preserved eclogite facies assemblages. Trace elements and REE patterns establish that eclogites protoliths are MORBs contaminated by continental crust. Standard thermobarometry and thermodynamic modelling are consistent with $P-T$ values of $640-740{ }^{\circ} \mathrm{C}$ for $1.5 \pm 0.25 \mathrm{GPa}$, coherent with paleo-geotherms predicted for warm subduction of oceanic crust. They interpret these eclogites as a dismembered cryptic suture zone. ${ }^{40} \mathrm{Ar} /{ }^{39} \mathrm{Ar}$ dating on amphiboles yields an age of $339.7 \pm 12 \mathrm{Ma}$ for eclogite retrogression under amphibolite facies conditions. All these data are combined to link the Argentera-Mercantour Massif in the tectonic framework of both pre-Mesozoic Alpine basement and European southern Variscides.
Ortolano et al. focus on the Sila Piccola Massif to obtain new constraints on the exhumation history of a relic fragment of the intermediate to deep portion of the Variscan basement, which now belongs to the northern Calabria Peloritani Orogen. The intermediate to deep portion of the Sila basement is characterised by a pervasive mylonitic horizon in orthogneiss and garnet paragneiss. An older metamorphic fabric occurs in low-strain domains, preserving an assemblage of plagioclase, biotite, white mica, sillimanite, quartz and first generation of garnet. The first mylonitization is associated with a late-Variscan extensional shearing, with a syn-kinematic growth of a second-generation garnet with plagioclase, biotite and quartz developed in the pressure shadows of garnet porphyroclasts. The second mylonitization, characterised by growth of chlorite, white mica, plagioclase and quartz along the C-planes, is interpreted as a late Alpine compressional overprint. The timescale of the late-Variscan shear-assisted exhumation stage is determined by diffusion-modelling and the strain rate of the Alpine event is determined by microstructurally derived paleopiezometry.

Hrouda and Chadima present a simple, but powerful geological approach to unravel the complex effects of tectonic/metamorphic overprinting of primary (sedimentary or igneous) magnetic fabrics. It is mostly based on previously published data and aims to analyse and summarize the different overprinting mechanisms. Even if more elaborate methods for magnetic anisotropy determination, that help to distinguish the subfabrics of different mineral classes or of different ferrimagnetic grain-size fractions exists, the authors demonstrate that a significant piece of information could be obtained by examining systematic relationships between site-level AMS and macroscopic fabric elements, and between the AMS of different rock types that have been subjected to similar overprinting stresses and temperatures.

Zucali et al. present in a very original way the relationships between the amount of finite strain and the degree of rock transformations under HP/LT metamorphism illustrated on one of the most classical, and important examples of subducted continental crust at Mt. Mucrone, Sesia-Lanzo Zone, Western Alps. Three classes of textural reworking (coronites, tectonites and mylonites) are defined, and the degree of recrystallization during HP-LT and LP-LT conditions is assessed. The domain of fabric evolution (DFE) and of metamorphic reaction progress (DRP) are then evaluated in $2 \mathrm{D}$ and $3 \mathrm{D}$. The modelling shows that the reaction progress and textural evolution are closely related in most cases and across different lithologies, but do not always coincide, mostly when DFE remains below the $60 \%$ threshold. The authors show that different volumes of the same rock preserved different parts of the tectonometamorphic evolution, and they can be determined and quantified. It has essential bearings and prospects on geodynamic models, as the 
heterogeneity of metamorphic and textural re-equilibration affects the thermo-mechanical behaviour of continental crust.

Plašienka et al. compare the evolution of two branches of the Pieniny Klippen Belt separating the Cretaceous nappe stack of the Central (Austroalpine) and the Cenozoic accretionary wedge of the External Western Carpathians (Flysch Belt). The western branch experienced a continuous NW-SE convergence and forward accretion of units derived from the foreland plate during the Late Cretaceous up to Oligocene. The developing accretionary wedge was supported by the backstop of the Central Carpathians. In contrast, the eastern branch originated by separation of PKB units and their dextral translation along the NE margin of the Central Carpathian block in the Late Eocene. During the Miocene, the situation reversed. The eastern branch was converted to the frontal backstop of the eastern part of the accretionary wedge, while the western branch became affected by alongstrike sinistral movements.

Fodor et al. examine Miocene deformation history of magmatic and host metamorphic rocks of the Pohorje pluton as well as the surrounding sediments to constrain the structural evolution of the Pohorje pluton during the onset of lithospheric extension at the Eastern Alps-Pannonian Basin transition. For this structural reconstruction, the work uses meso- and microscale structures and anisotropy of magnetic susceptibility data. Based on the new and already published data, a new evolutionary scheme of the Pohorje pluton is developed.

Tian et al. report detailed structural results on the North Liaohe Group, an important Paleoproterozoic sedimentary sequence in NE China. Two structural features are recognized in this study, i.e. a Paleoproterozoic thrust within the Langzishan formation and a Cretaceous metamorphic complex formed above underlying Archean gneisses. The structural analysis combined with metamorphic and geochronological data is used for identification of a multi-stage evolution. These new findings have great implications to the evolutionary history of the North China Craton.

Gong et al. present Os-isotopic data for mantle peridotites from two representative Paleozoic ophiolites for western Chinese Tianshan. High degree of Os-isotopic heterogenity is revealed for the Paleo-Asian oceanic upper mantle, similar to those observed in modern convective upper mantle. The presence of Os-isotopically ultradepleted domains is notable, which reflects Proterozoic melt depletions. This might support the general hypothesis that isotopically ultradepleted (i.e. ancient) domains are inherent components of the convecting upper mantle and have not been sufficiently homogenized by convection. Further comparison showed that some of the ancient domains may represent ancient recycled subcontinental lithospheric mantle, which were then exhumed to form the substrate of oceanic basins.

$\mathrm{Li}$ et al. focused on the early Paleozoic granitoids in the Harizha area of the East Kunlun Orogenic Belt, China, to discuss closure timeframe and evolution of the Proto-Tethys Ocean. LA-ICP-MS zircon dating shows that the granodiorite and monzonitic granite were emplaced at $447.9 \pm 3.0 \mathrm{Ma}$ and $443.8 \pm 3.5 \mathrm{Ma}$. The granodiorite is typical adakitic high- $\mathrm{Mg}$ andesite, possibly derived from mixing between crustal melts and magma from the metasomatized mantle in a subduction setting. The monzonitic granite is a typical S-type granite, originated from partial melting of crustal clastic materials. It is suggested that the granodiorite and monzonitic granite were formed during a tectonic transition from subduction to collision. A transverse diachronic closure model of the "earlier on the sides, later in the middle" is proposed for the evolution of the Proto-Tethys.

Lehmann et al. propose a new interesting model for one of the world's largest $\left(\geq 15,000 \mathrm{~km}^{2}\right)$, but also least studied anorthosite-mangerite-charnockite-granite suites-the Kunene Complex in Angola. Based on structural data, and $\mathrm{U}-\mathrm{Pb}$ zircon and ${ }^{40} \mathrm{Ar} /{ }^{39} \mathrm{Ar}$ amphibole and mica geochronology they suggest anorthosite emplacement in a compressional setting. In their model, anorthosite sheets were emplaced at a high angle to the shortening direction and along host-rock anisotropy deep in the crust and cooled during progressive ductile thrusting and exhumation of the country rocks.

Martelat et al. use gravity data, integrated with recent seismic data, to investigate the Moho geometry in southern Madagascar. A key observation is that $15 \mathrm{~km}$ wide and at least $600 \mathrm{~km}$ long ductile shear zones of Ediacaran age coincide with linear positive anomalies of Bouguer gravity. The anomalies, highlighted by the high-pass filter derivative of gravity data, suggest a link with deep-seated high-density material. The gravity anomalies are linked to narrow mantle cusps at the base of continental lithosphere. The Bouguer gravity anomalies are further interpreted as features produced by vertical material transfer within shear zones that was enabled by mutual coupling between the crust and lithospheric mantle. The vertical mantle rise was enhanced by a negligible density contrast across the Moho. The mantle cusps are thought to develop during important horizontal shortening of the crust-mantle interface. The case study presented is considered an argument in favour of crust-mantle coupling as a general feature of hot orogens. 